\title{
Valorization of Agro-industrial Discards in Fermentation for the Production of Cellulase Enzyme
}

\author{
Aparna Dinil (D) and Anu Jacob* (D) \\ Department of Biotechnology, Karunya Institute of Technology and Sciences, Coimbatore - 641114 , \\ Tamil Nadu, India.
}

\begin{abstract}
Cellulases are commercially important enzymes with application in various industries such as biofuel, detergent, food processing, brewery, pulp and paper. To make its production cost-effective, a preferred method is to use solid-state fermentation and with use of inexpensive substrates. Solid-state fermentation is an alternative culturing method and yields higher enzymes compared to submerged fermentation. In the current study, Aspergillus niger was isolated and further developed as inoculum for solid-state fermentation. Agroindustrial discards like banana pseudostem, jackfruit waste were used as the substrates. The substrates were pretreated by acid and were characterized by FTIR analysis to confirm the presence of cellulosic content. Different concentrations of the substrates were attempted for fermentation and the yield of the enzyme was compared. The solid-state fermentation was stable for enzyme production as well as microbial growth. The cellulase activity per gram of the substrate $(\mathrm{U} / \mathrm{g})$ was obtained maximum for jackfruit waste-based media $(17 \pm 1.1 \mathrm{U} / \mathrm{g})$. Both the lignocellulosic substrates were potential substrates for the production of cellulase enzyme. With further optimization and scale-up, this could be a cheap and sustainable process. This study has validated agro-industrial waste's bioconversion into value-added products that have a remarkable environmental and economic advantage.
\end{abstract}

Keywords: Banana pseudostem, cellulase, jackfruit waste, solid-state fermentation

(C) The Author(s) 2022. Open Access. This article is distributed under the terms of the Creative Commons Attribution 4.0 International License which permits unrestricted use, sharing, distribution, and reproduction in any medium, provided you give appropriate credit to the original author(s) and the source, provide a link to the Creative Commons license, and indicate if changes were made. 


\section{INTRODUCTION}

India is a leading producer of fruits and it leaves large-volume wastes that need to be processed. The transformation of this waste into a valuable product is a better option than waste treatment. Enormous quantities of agroindustrial wastes that are mainly composed of lignocellulosic material are accumulating every year. Solid-state fermentation (SSF) holds potential in the utilization of these agro-industrial wastes as substrates for the production of enzymes. ${ }^{1}$ Compared to Submerged fermentation (SmF), SSF has advantages such as low water requirement, lower chances of contamination, low energy consumption, flexibility to follow simple methods for separation and purification of products, ${ }^{2}$ reduction in catabolite repression which leads to higher production. ${ }^{3} \mathrm{~A}$ reduction in the cost of production has been observed from $\$ 20 / \mathrm{kg}$ for SmF to $\$ 0.2 / \mathrm{kg}$ for SSF. ${ }^{4}$ Fungal species such as Aspergillus niger and Trichoderma sp. are capable of producing cellulase enzymes. A niger produces endoglucanase and b-glucosidase, while the later produce endoglucanase and exoglucanase along with low proportion of b-glucosidase. ${ }^{5}$ Cellulases are widely utilized in the biofuel industry. ${ }^{6}$ Cellulases contribute a significant part in cost towards bioethanol production $(40 \%$ of total cost) with lignocellulosic material. ${ }^{7,8}$ Hence the cost reduction in its production is considered a sought after endeavour. Cellulase production depends majorly on the carbon source, its degradability, composition, the access of microbes to the substrates. ${ }^{9}$ In solid-state fermentation, the substrates act as the support for microbe growth as well as the required aeration is achieved through the void space between substrate particles. The water absorption capacity of substrate particles is important since microbes depend on it for growth and enzyme production. ${ }^{9}$ All these will contribute towards differential production of the enzyme in different substrates. Moreover, substrate cost has been evaluated to be more than $30 \%$ of the total enzyme production cost by fermentation. ${ }^{10}$

India being a leading producer of bananas in the world with a production of about 14.2 million tons in a year, ${ }^{11}$ a very large quantity of waste is accumulated as the ratio of banana waste to product is $2: 1$. In jackfruit, the waste portion accounts for about $65-55 \%$ against an edible portion of $25-35 \% .{ }^{12}$ The waste generated from these agro-industrial processes are usually dumped to the environment with treatments such as burning. Hence the rich bioactive resources are underutilized and add to the pollution load on the environment. Valorizing the waste from these industries is desired to reduce the pollution effects related to its treatment and disposal. This study is an effort to transform large-volume agroindustrial wastes from fruit crops such as banana pseudostem and jackfruit waste under solid-state fermentation to produce cellulase enzymes. This study will help in the development of low cost methodology for the industrial production of cellulase as there are limited studies on the utilization of banana pseudostem and jackfruit waste are available.

\section{METHODOLOGY}

\section{Screening and Isolation of the Microorganism}

The fungal culture used in the study was isolated from a spoiled onion. Spoiled onions with black fungal growth were collected from the local market. The onions were sliced without affecting the fungal colony and were crushed in mortar and pestle with the addition of distilled water. ${ }^{13}$

The distilled water with fungal spore suspended was inoculated into Potato dextrose agar (PDA) under sterile conditions by spread plate technique. The culture was incubated for 7-10 days at $27-30^{\circ} \mathrm{C} .{ }^{14}$ The potato dextrose agar medium was composed of (per $1000 \mathrm{ml}$ ) potato infusion form (200g), dextrose (20g), agar (15g).

The fungus grown on PDA was inoculated onto a carboxymethyl cellulose agar medium under sterile conditions for screening cellulase producing fungi. The culture was incubated at $27-30^{\circ} \mathrm{C}$ for 7 days. After the incubation period, $1 \%$ Congo red stain was used to stain the fungi for $1 \mathrm{hr}$, and then it was washed off using $1 \% \mathrm{NaCl}$. The cultures were observed for the zone of hydrolysis around the fungus. ${ }^{15}$ The screening medium was prepared with carboxymethyl cellulose sodium salt (6.5g), yeast extract $(0.25 \mathrm{~g}) \mathrm{NH}_{4} \mathrm{H}_{2} \mathrm{PO}_{4}(0.25 \mathrm{~g}), \mathrm{KCl}$ (0.05g), $\mathrm{MgSO}_{4} .7 \mathrm{H}_{2} \mathrm{O}(0.25 \mathrm{~g})$, agar (1g) and was sterilized at $121^{\circ} \mathrm{C}$ for $15-20$ mins, 15 psi.

The culture morphologies were identified with lactophenol cotton blue staining. The procedure followed was placing $70 \%$ ethanol onto a microscopic glass slide and then immersed a loop 
full of culture in the drop of alcohol. One or two drops of the lactophenol cotton blue stain were added to the culture and a coverslip was placed on it without the formation of air bubbles. The slide was subsequently examined in the microscope with 40X objective power. ${ }^{16}$ The culture was then analyzed by MALDI TOF for preliminary identification.

\section{Substrate preparation}

The lignocellulosic materials collected for the study were banana plant pseudostem and jack fruit waste for producing cellulase enzyme in solid-state fermentation.

\section{Pretreatment of Banana Pseudostem}

Banana plant pseudostem was obtained from the agricultural fields in Kerala. Then it was cut into small pieces and allowed to dry under sunlight for about 2 weeks. The dried stem was rinsed several times with distilled water, neutralized with $0.1 \mathrm{M} \mathrm{HCl}$ and finally washed with distilled water. ${ }^{16}$ Again the sample was dried under the sun, after drying it was powdered for the fermentation process. The powdered banana stem was given for Fourier-transform infrared spectroscopy to determine the amount of cellulose. Different media were prepared with a composition of 10,5 and $2 \mathrm{~g}$ of powdered banana plant pseudostem along with peptone and distilled water for the production of the enzyme. The media were sterilized in an autoclave at $121^{\circ} \mathrm{C}, 15 \mathrm{psi}$ for 20 minutes and were cooled to room temperature for inoculation of the organism.

\section{Pretreatment of Jackfruit Waste}

Jackfruit waste obtained from the agricultural fields of Kerala was cut into small pieces and allowed to dry under sunlight for about 2 weeks. The dried sample was rinsed several times with distilled water, neutralized with $0.1 \mathrm{M} \mathrm{HCl}$ and finally washed with distilled water. Again the sample is dried under the sun, after drying it was powdered for the fermentation process. The powdered jack fruit waste was given for Fourier-transform infrared spectroscopy to determine the amount of cellulose. Different media were prepared with varying concentrations of the substrate (Table 1 ) and were sterilized in an autoclave at $121^{\circ} \mathrm{C}, 15 \mathrm{psi}$ for $15-20$ minutes and were cooled to room temperature for inoculating organisms.

\section{Enzyme Production}

The inoculum for the production media was raised in sterile Czapek-Dox media (Himedia). About $0.02 \mathrm{~g}$ of mat formed in the broth was taken and inoculated in the different production media in

Table 1. Composition of Jackfruit Waste medium

\begin{tabular}{lcccccc}
\hline Ingredients/Media & B1 & B2 & B3 & J1 & J2 & J3 \\
\hline Banana pseudostem & $10 \mathrm{~g}$ & $5 \mathrm{~g}$ & $2 \mathrm{~g}$ & - & - & - \\
Jackfruit waste & - & - & - & $10 \mathrm{~g}$ & $5 \mathrm{~g}$ & $2 \mathrm{~g}$ \\
distilled water & $15 \mathrm{ml}$ & $7.5 \mathrm{ml}$ & $3 \mathrm{ml}$ & $15 \mathrm{ml}$ & $7.5 \mathrm{ml}$ & $3 \mathrm{ml}$ \\
Peptone & $4 \mathrm{~g}$ & $2 \mathrm{~g}$ & $0.8 \mathrm{~g}$ & $4 \mathrm{~g}$ & $2 \mathrm{~g}$ & $0.8 \mathrm{~g}$ \\
\hline
\end{tabular}

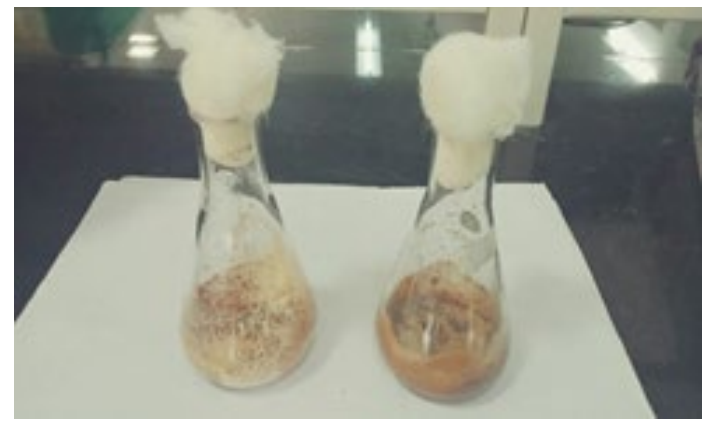

Fig. 1. Solid state fermentation of banana pseudostem and jack fruit waste.

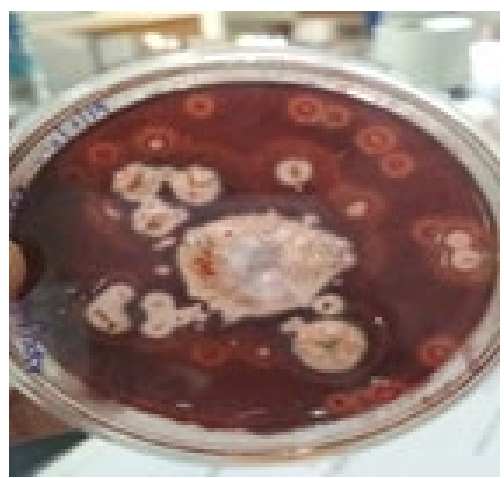

Fig. 2. Zone of hydrolysis in carboxymethyl cellulose agar. 
$250 \mathrm{ml}$ conical flasks (Fig. 1). The flasks were then incubated at $30^{\circ} \mathrm{C}$ in a humidified incubator for a period of $96 \mathrm{~h} .{ }^{17}$

\section{Extraction of enzyme}

The enzyme was extracted from lignocellulose substrate by mixing it homogenously $(1: 10 \% \mathrm{w} / \mathrm{v})$ with sodium citrate buffer $(\mathrm{pH}=5)$. Then it was agitated on a rotary shaker (120 rpm) at $30^{\circ} \mathrm{C}$ followed by filtering it using a muslin cloth to remove the fungal mat. Subsequently, it was centrifuged at $6000 \mathrm{rpm}$ in a cooling centrifuge $\left(4^{\circ} \mathrm{C}\right)$ for $15 \min ^{18}$ The supernatant obtained was subjected for further assay such as protein estimation by Lowry's method and carboxymethyl cellulase assay

\section{Enzyme Assay}

To the enzyme extract, $1 \% \mathrm{CMC}$ in citrate buffer $(5 \mathrm{mM}, \mathrm{pH} 5)$ was added and released glucose levels were measured by the method of DNS (3,5dinitrosalycylic acid). One unit of enzymatic activity was expressed as the

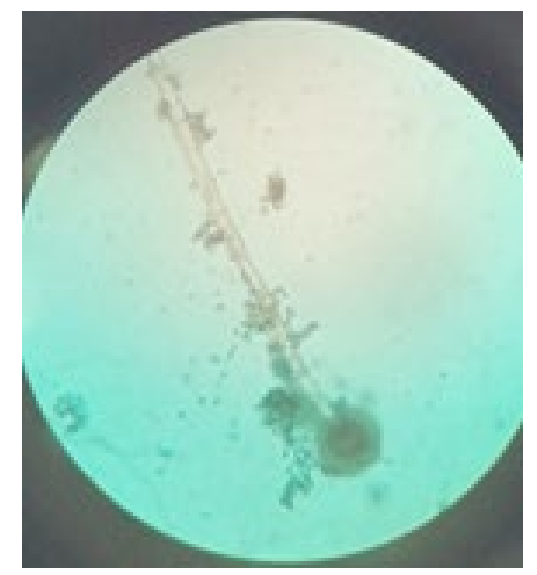

Fig. 3. Microscopic view of isolate.

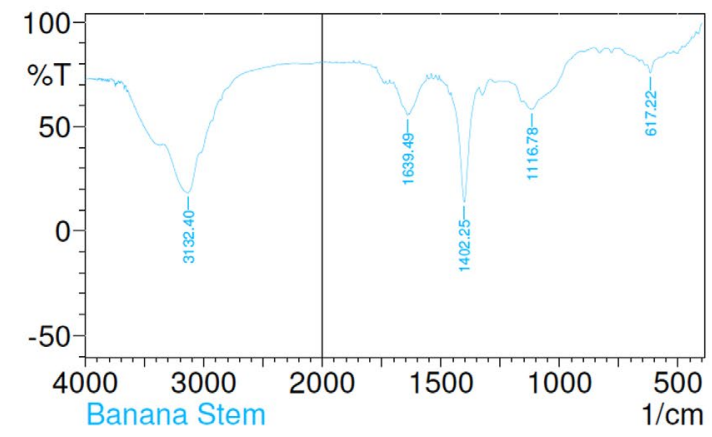

concentration of enzyme that released $1 \mu \mathrm{g}$ of reducing sugar from the substrate per minute under assay conditions.

\section{Statistical analysis}

The experiments were carried out in triplicates and the data were statistically analyzed One-way analysis of variance (ANOVA) test using MS Excel 2010. Differences were considered significant when the probability value $(p)$ was $<0.05$. The error bars in the graphs represent standard error.

\section{RESULTS AND DISCUSSION \\ Isolation, Screening and Identification of the organism}

The fungal isolates obtained from the onion were subjected to a screening test. The isolates were grown on carboxymethyl cellulose agar and the isolate displayed zone of hydrolysis on the agar plate (Fig. 2) was chosen for further identification. The zone of clearance around the culture indicates the potential of organism to produce a significant amount of enzyme. The zone of hydrolysis formed around the fungal colony indicated its ability to produce cellulase enzyme. ${ }^{19}$ The organism was identified as Aspergillus niger by the MALDI TOF analysis. MALDI TOF MS is a cost-effective, time-saving method of high throughput for an accurate working protocol for identifying filamentous fungi. ${ }^{20}$ Under microscopic observation (Fig. 3) with lactophenol cotton blue staining, the colony displayed translucent septate hyphae with a large conidial head. The conidiophores were brownish and the spherical vesicle with sterigmata on the surface. ${ }^{21}$ The morphology is hardly correlated to the yield in fermentation, however, the filamentous fungi

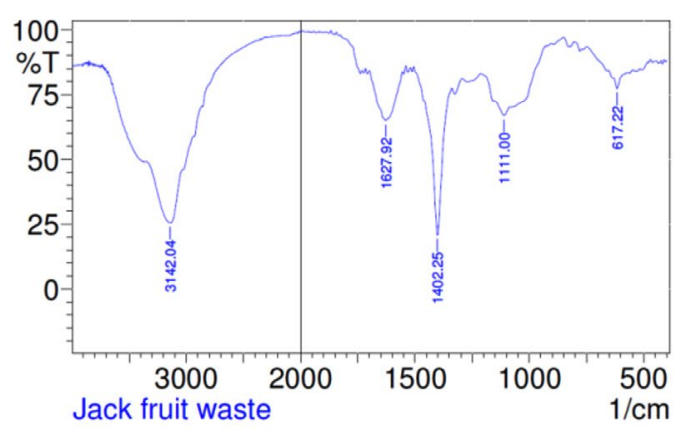

Fig. 4. FTIR Spectra of banana pseudostem and jackfruit waste. 
have advantage of growing on the surfaces and exhibits a distinctive physiological behaviour. The productivity of cellulase enzyme by Aspergillus niger is more in solid state fermentation compared to submerged fermentation. ${ }^{22}$

\section{Characterization of the substrates}

Banana pseudostem is formed with collection of leaf stalk bases to give rise to a cylindrical structure. ${ }^{23}$ It is composed of cellulose, hemicellulose, and lignin. Pretreatment of the pseudostem exposes the carbohydrate polymers and hence allowing enhanced enzyme access for better enzymatic hydrolysis (saccharification).

FTIR analysis (Fig. 4) was performed for the substrates used in solid-state fermentation to verify the presence of functional groups in it. FTIR spectra were recorded in the region of 4000 $400 \mathrm{~cm}^{-1}$ on an IR Prestige 21 Fourier Transform Infrared Spectrum (Shimadzu) housed at $25^{\circ} \mathrm{C}$, $50 \%$ relative humidity. The occurrence of polymers such as cellulose, hemicellulose and lignin in the substrate gave rise to many $\mathrm{OH}$ bonds in the sample. The properties and activity of the material depends on the presence of the functional groups such as carboxyl, hydroxyl, phenols, amide, acylamino, and phosphate. ${ }^{24,25}$ All through the FTIR analysis, the energy from infrared radiation was absorbed by the covalent bonds present in the functional groups and it caused the bonds to be stretched. This leads to the stretching in $\mathrm{OH}$ bonds to increase the sharpness or broadness on the peaks in the spectrum. ${ }^{26}$ In the infrared spectroscopy (Table 2), peaks were dominated by the existence of strong bands at $3000-3500$ $\mathrm{cm}^{-1}$, which relates to the hydrogen-bonded $\mathrm{O}-\mathrm{H}$ stretching of hydroxyl groups corresponding to cellulose and hemicelluloses. ${ }^{27}$ It also indicated a strong inter and intramolecular binding of the polysaccharide chain. ${ }^{28,29}$ The peak in the range of 1630-1650 corresponds to free carboxyl group present in the sample. ${ }^{30}$ The main functional groups in the polysaccharide such as ether R-O-R and cyclic $\mathrm{C}-\mathrm{C}$ bonds were corresponding to the peak in the range of $950-1200 \mathrm{~cm}^{-1}$. This region is also regarded as 'finger print' for carbohydrates. ${ }^{31}$ The abundance of $\mathrm{C}-\mathrm{O}, \mathrm{C}-\mathrm{C}$ ring in the region of $1200-850 \mathrm{~cm}^{-1}$ represents polysaccharide ${ }^{32}$ and the existence of glycoprotein carbohydrates. ${ }^{33}$

Table 2. Spectral observations entailing quantification in molecular vibrations (peak area) in all the samples

\begin{tabular}{lcccccccc}
\hline Sample/ wave No. & 617.22 & 1111 & 1116.78 & 1402.25 & 1627.92 & 1639.49 & 3132.4 & 3142.04 \\
\hline Banana pseudostem & 5.266 & - & 16.077 & 43.372 & - & 11.272 & 62.644 & - \\
Jackfruit waste & 7.244 & 11.014 & - & 39.469 & 20.326 & - & - & 96.235 \\
\hline
\end{tabular}

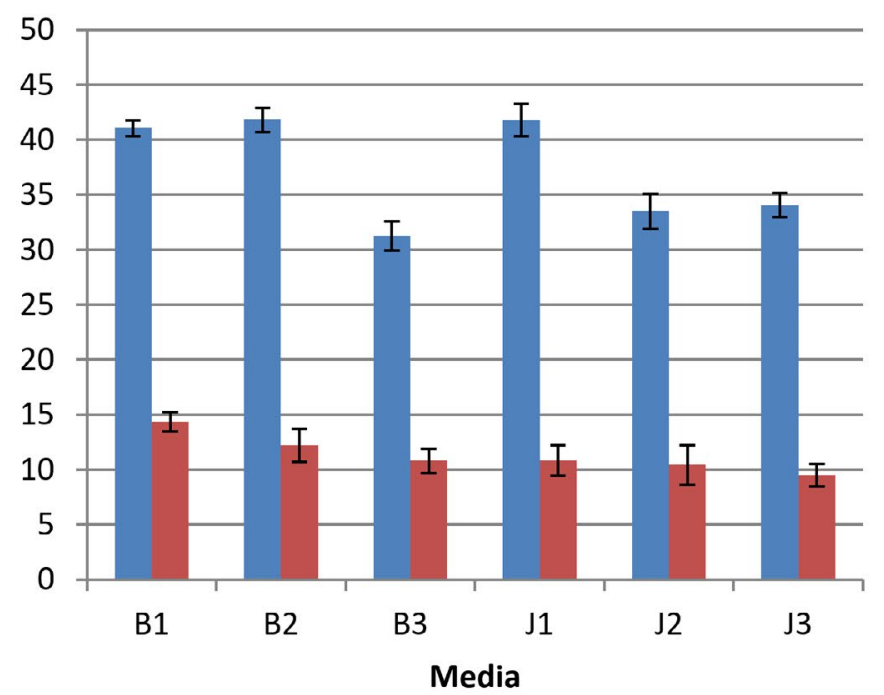

Cellulase activity (micromol product released per min)

Protein $\mathrm{mg} / \mathrm{ml}$

Fig. 5. Comparison of different media on cellulose activity and protein. 
The peak in the region of $1300-800 \mathrm{~cm}^{-1}$ is the representation of fingerprint region of pectin polysaccharide. It also reveals some modifications in monosaccharide composition. ${ }^{34}$ Peaks in the region $1400-1450 \mathrm{~cm}^{-1}$ represents salts of carboxyl groups. ${ }^{35}$

\section{Production of Enzyme}

After $96 \mathrm{~h}$ of incubation in the production media, cultures were harvested and an enzyme assay was done to measure the cellulase activity (Fig. 5). Protein production was observed more in media B1 while enzymatic activity was more in media B2 and J1. For both jackfruit waste-based as well as banana pseudo-stem-based media, the high concentration of solid substrate was favouring the improvement in production as well as activity of cellulase. The cellulase activity per gram of the substrate $(\mathrm{U} / \mathrm{g})$ was obtained as $4.1,8.3,15.6,4.1,6.7$, and 17.0 for B1, B2, B3, $\mathrm{J} 1, \mathrm{~J} 2$ and $\mathrm{J} 3$ respectively. The mean comparison showed that the cellulase activity per gram of the substrate is significantly different ( $p$-value $<0.05$ ) between the 6 different media attempted. Both the lignocellulosic substrates are potential substrates for the production of cellulase enzymes. In the production of cellulase enzyme with coir waste as substrate using $A$ niger, after optimization studies, a maximum of $9 \mathrm{U} / \mathrm{g}$ was observed as the cellulase activity. ${ }^{36}$ In another study using $A$ niger in SSF with cellulose-rich substrates such as corncob and sugar cane, cellulase activity was observed to be $1.22 \mathrm{U} / \mathrm{ml}$, and $0.14 \mathrm{U} / \mathrm{ml}$ respectively. ${ }^{37}$ The differences in the cellulase activity in different substrates are based on the cellulosic composition, macro and microelements as well as lignin content. ${ }^{38}$ Pretreatment of the material is essential to separate cellulose and hemicellulose from cell wall as it undergoes lignification. ${ }^{39}$ Jackfruit waste $^{40}$ composed of hemicellulose $(16.27 \%)$, cellulose $(22.78 \%)$ and lignin $(20.41 \%)$ while Banana pseudostem ${ }^{41}$ consist of lignin $(10.4 \%$ $\mathrm{w} / \mathrm{w})$, cellulose $(28.6 \% \mathrm{w} / \mathrm{w})$, hemicellulose $(14.7 \%$ w/w). The results indicate that Aspergillus niger could be grown in SSF using both the substrates. The study confirmed that the agro-industrial waste as the substrate in solid state fermentation will be a sustainable approach to produce enzymes.

\section{CONCLUSION}

Agro-industrial wastes such as banana pseudostem and jackfruit peel wastes were used in the production of cellulase in solidstate fermentation. These are a rich source of lignocellulosic material and are suitable for large scale production of cellulase. The utilization of these waste materials considerably reduces the load of pollution and energy requirement in processing them. Both the substrates were proved to be effective in cellulase production using $A$ niger in SSF. Jackfruit waste proved better compared to banana pseudostem for the cellulolytic activity. Further process parameter optimization and media optimization can enhance the yield of cellulase enzyme in the case of the substrates used in this study as well.

\section{ACKNOWLEDGMENTS}

None.

\section{CONFLICT OF INTEREST}

The authors declare that there is no conflict of interest.

\section{AUTHORS' CONTRIBUTION}

All authors listed have made a substantial, direct and intellectual contribution to the work, and approved it for publication.

\section{FUNDING}

None.

\section{DATA AVAILABILITY}

All datasets generated or analyzed during this study are included in the manuscript.

\section{ETHICS STATEMENT}

Not applicable.

\section{REFERENCES}

1. Singhania R, Patel KA, Thomas L, Goswami IM, Giri S, Pandey A. Industrial Enzymes. Industrial Biorefineries \& White Biotechnology. Elsevier. 2015:473-497. doi: 10.1016/B978-0-444-63453-5.00015-X

2. El-Shishtawy R, Mohamed, SA, Asiri A, Abu-bakr M, Ibrahim I, Al-Talhi H. Solid fermentation of wheat bran for hydrolytic enzymes production and saccharification content by a local isolate Bacillus megatherium. BMC Biotechnol. 2014;14(1):1-8. doi: 10.1186/1472-675014-29

3. Kar S, Gauri SS, Das A, et al. Process optimization of xylanase production using cheap solid substrate by Trichoderma reesei SAF3 and study on the alteration 
of behavioral properties of enzyme obtained from SSF and SmF. Bioprocess Biosyst Eng. 2013;36(1):57-68. doi: 10.1007/s00449-012-0761-x

4. Oberoi HS, Chavan Y, Bansal S, Dhillon GS. Production of cellulases through solid state fermentation using kinnow pulp as a major substrate. Food Bioprocess Technol. 2010;3(4):528-536. doi: 10.1007/s11947-0080092-8

5. Sohail M, Siddiqi R, Ahmad A, Khan SA. Cellulase production from Aspergillus niger MS82: effect of temperature and pH. N Biotechnol. 2009;25(6):437441. doi: 10.1016/j.nbt.2009.02.002

6. Yan $\mathrm{S}, \mathrm{Wu} \mathrm{G}$. Secretory pathway of cellulase: a minireview. Biotechnol Biofuels. 2013;6(1):177. doi: 10.1186/1754-6834-6-177

7. Ellila S, Fonseca L, Uchima C, et al. Development of a low-cost cellulase production process using Trichoderma reesei for Brazilian biorefineries. Biotechnol Biofuels. 2017;10(1):1-7. doi: 10.1186/ s13068-017-0717-0

8. Arora R, Behera S, Kumar S. Bioprospecting thermophilic/thermotolerant microbes for production of lignocellulosic ethanol: a future perspective. Renew Sustain Energy Rev. 2015;51:699-717. doi: 10.1016/j. rser.2015.06.050

9. Gautam A, Kumar A, Dutt D. Production of cellulasefree xylanase by Aspergillus flavus ARC-12 using pearl millet stover as the substrate under solid-state fermentation. J Adv Enzym Res. 2015;1:1-9.

10. Yegin S, Buyukkileci A, Sargin S, Goksungur Y. Exploitation of agricultural wastes and by-products for production of Aureobasidium pullulans Y-2311-1 xylanase: screening, bioprocess optimization and scale up. Waste and Biomass Valorization. 2017;8(3):9991010. doi: $10.1007 / \mathrm{s} 12649-016-9646-6$

11. Horticulture BN. Report on Banana. 2017. http://nhb. gov.in/report_files/banana/BANANA.htm, Accessed on 1 August 2021

12. Swami S, Thakor N, Haldankar P, Kalse S. Jackfruit and its many functional components as related to human health: a review. Compr Rev Food Sci Food Saf. 2012;11(6):565-576. doi: 10.1111/j.15414337.2012.00210.x

13. Chandraker D, Sao S, Deshmukh Y, Verma L, Sahu P. Isolation of Aspergillus niger from Allium cepa bulb and production of citric acid from it. Int J Pharma Bio Sci. 2014;5(1):144-147.

14. Wen Z, Liao W, S Chen. Production of cellulase/ $\beta$ glucosidase by the mixed fungi culture Trichoderma reesei and Aspergillus phoenicis on dairy manure. Process Biochem. 2005;40(9):3087-3094. doi: 10.1016/j.procbio.2005.03.044

15. Pachauri P, More S, Aranganathan V, Sullia S, Deshmukh S. Kinetic study and characterization of cellulase enzyme from isolated Aspergillus niger subsp. awamori for cellulosic biofuels. J Sci Ind Res. 2018;77(1):55-60.

16. Milala M, Shugaba A, Gidado A, Ene A, Wafar J. Studies on the use of agricultural wastes for cellulase enzyme production by Aspergillus niger. Res J Agric Biol Sci. 2005;1(4):325-328.

17. Abo-State MAM, Swelim M, Hammad Al, Gannam RB. Some critical factors affecting cellulase (S) production by Aspergillus terreus Mam-F23 and Aspergillus flavus Mam-F35 under solid-state fermentation of wheat straw. World App/ Sci J. 2010;9(10):1171-1179.

18. Chandra M, Kalra A, Sangwan NS, Gaurav SS, Darokar MP, Sangwan RS. Development of a mutant of Trichoderma citrinoviride for enhanced production of cellulases. Bioresour Technol. 2009;100(4):1659-1662. doi: 10.1016/j.biortech.2008.09.011

19. Zhang XZ, Zhang YH. Cellulases: characteristics, sources, production, and applications. Bioprocess Technol Biorefinery Sustain Prod fuels, Chem Polym. 2013;1:131-146. doi: 10.1002/9781118642047.ch8

20. Peng $Y$, Zhang $Q, X u C$, Shi W. MALDI TOF MS for the rapid identification and drug susceptibility testing of filamentous fungi. Exp Ther Med. 2019;18(6):48654873. doi: $10.3892 /$ etm. 2019.8118

21. Devanathan $G$, Shanmugan $T$, Balasubramanian, $T$ Manivannan S. Cellulase production by Aspergillus niger isolated from coastal mangrove debris. Trends Appl Sci Res. 2007;2(1):23-27. doi: 10.3923/ tasr.2007.23.27

22. Gamarra NN, Villena GK, Gutierrez-Correa M. Cellulase production by Aspergillus niger in biofilm, solidstate, and submerged fermentations. Appl Microbiol Biotechnol. 2010;87(2):545-551. doi: 10.1007/s00253010-2540-4

23. Mukhopadhyay S, Fangueiro R, Arpac $Y$, Senturk $U$. Banana fibers-variability and fracture behaviour. J Eng Fiber Fabr. 2008;3(2):39-45. doi: $10.1177 / 155892500800300207$

24. Leong YK, Chang JS. Bioremediation of heavy metals using microalgae: recent advances and mechanisms. Bioresour Technol. 2020;303:122886. doi: 10.1016/j. biortech.2020.122886

25. Heidari P, Panico A. Sorption Mechanism and Optimization Study for the Bioremediation of $\mathrm{Pb}$ (II) and Cd (II) Contamination by Two Novel Isolated Strains Q3 and Q5 of Bacillus sp. Int J Environ Res Public Health. 2020;17(11):4059. doi: 10.3390/ijerph17114059

26. Azizan A, Shafaei NSM, Sidek N, Hanafi F, Mokti N, Zaharudin S. Fourier Transform Infrared Spectroscopy interpretation on pretreated Acacia auriculiformis, Melastoma malabathricum and Leucaeana leucocephala. Int J Appl Eng Res. 2016;11(20):1004810051.

27. Sundarraj AA, Ranganathan TV. Physicochemical characterization of jackfruit (Artocarpus integer (Thumb.)) Peel. Res J Pharm Biol Chem Sci. 2017;8(3):2285-2295.

28. Wu J, Zheng J, Xia X, Kan J. Purification and structural identification of polysaccharides from bamboo shoots (Dendrocalamus latiflorus). Int J Mol Sci. 2015;16(7):15560-15577. doi: 10.3390/ijms160715560

29. Wang Z, Zhou F, Quan Y. Antioxidant and immunological activity in vitro of polysaccharides from Phellinus nigricans mycelia. Int J Biol Macromol. 2014;64:139143. doi: 10.1016/j.ijbiomac.2013.11.038

30. Gnanasambandam R, Proctor A. Determination of pectin degree of esterification by diffuse reflectance Fourier transform infrared spectroscopy. Food Chem. 2000;68(3):327-332. doi: 10.1016/S03088146(99)00191-0 
31. Cerna M, Barros A, Nunes A, et al. Use of FT-IR spectroscopy as a tool for the analysis of polysaccharide food additives. Carbohydr Polym. 2003;51(4):383-389. doi: 10.1016/S0144-8617(02)00259-X

32. Zhu K, Zhang $\mathrm{Y}, \mathrm{Nie} \mathrm{S}$, et al. Physicochemical properties and in vitro antioxidant activities of polysaccharide from Artocarpus heterophyllus Lam. pulp. Carbohydr Polym. 2017;155:354-361. doi: 10.1016/j.carbpol.2016.08.074

33. Fang $X$, Yin $X$, Yuan $G$, Chen $X$. Chemical and biological characterization of polysaccharides from the bark of Avicennia marina. Eur Food Res Technol. 2015;241(1):17-25. doi: 10.1007/s00217-015-2430-1

34. Zhang W, Zeng G, Pan Y, et al. Properties of soluble dietary fiber-polysaccharide from papaya peel obtained through alkaline or ultrasound-assisted alkaline extraction. Carbohydr Polym. 2017;172:102112. doi: 10.1016/j.carbpol.2017.05.030

35. Pecsok R, Shields L, Cairns T, McWilliam I. Modern Method of Chemical Analysis. New York: Wiley; 1976.

36. Mrudula S, Murugammal R. Production of cellulase by Aspergillus niger under submerged and solid state fermentation using coir waste as a substrate. Brazilian J Microbiol. 2011;42:1119-1127. doi: 10.1590/S151783822011000300033

37. Bhoosreddy GL. Comparative study of cellulase production by Aspergillus niger and Trichoderma viride using solid state fermentation on cellulosic substrates corncob, cane bagasse and sawdust. Int I Sci Res. 2014;3(5):324-326.

38. Abdullah B, Maftukhah S, Listyaningrum E, Faradhiba F. Effect of some variable in cellulase production by Aspergillus niger ITBCC L74 using solid state fermentation. IOP Conf Ser Mater Sci Eng. 2018;316(1):012066. doi: 10.1088/1757899X/316/1/012066

39. Nee'Nigam PS, Gupta N, Anthwal A. Pre-treatment of Agro-Industrial Residues. Nigam PS nee', Pandey A, eds. Biotechnology for Agro-Industrial Residues Utilisation. Springer Dordrecht; 2009:13-33. doi: 10.1007/978-1-4020-9942-7_2

40. Alves JLF, Silva JCG da, Mumbach GD, et al. Insights into the bioenergy potential of jackfruit wastes considering their physicochemical properties, bioenergy indicators, combustion behaviors, and emission characteristics. Renew Energy. 2020;155:1328-1338. doi: 10.1016/j. renene.2020.04.025

41. Pereira ALS, do Nascimento DM, Men de Sam Souza MS, et al. Banana (Musa sp. cv. Pacovan) pseudostem fibers are composed of varying lignocellulosic composition throughout the diameter. BioResources. 2014; 9(4):7749-7763. doi: 10.15376/ biores.9.4.7749-7763 